\title{
EMPLOYMENT EFFECTS OF DIFFERENT MUNICIPAL WASTE TREATMENT SYSTEMS BASED ON DATA FROM AUSTRIA
}

\author{
Roland Pomberger ${ }^{1, *}$, Michael Altendorfer ${ }^{1}$ and Ulrike Gelbmann ${ }^{2}$ \\ ${ }^{1}$ Department of Waste Processing Technology and Waste Management, Montanuniversitaet, Franz-Josef-Straße 18, 8700 Leoben, \\ Austria \\ 2 Institute of Systems Sciences, Innovation and Sustainability Research, University of Graz, Merangasse 18, 8010 Graz, Austria
}

Article Info:
Received:
12 August 2020
Revised:
11 March 2021
Accepted:
12 March 2021
Available online:
15 June 2021
Keywords:
Residual waste
Employment effects
Collection
Analyses of residual waste
Waste management
Austria

\section{INTRODUCTION}

Waste management is an important sector of the economy and has over the last 50 years changed significantly in Europe. Many countries have moved from a rudimentary stage of "disregarding waste" to a sophisticated stage of "industrial material cycles" (Klampfl-Pernold \& Gelbmann 2006). The last stage involves comprehensive recycling and reuse of the material contained in waste and is reinforced by the objectives of the Circular Economy (EC 2015), as well as the European Green Deal (EC 2019) and the Climate Neutrality Strategy 2050 (EC 2018). Recycling, however, requires a more elaborate collection system and a more intensive treatment of waste - and this increases the number of employees involved in the activities. Although waste enterprises might not appreciate this fact, it could be a contribution to job creation within the European Union (EU).

The employment effects in waste management have so far hardly been considered. Studies commissioned by the
European Commission (EC) provide values on the increase in direct jobs scenarios of increasing recycling (Hogg, Vergunst, Elliott, Elliott, \& Corbin 2016; Gibbs et al. 2014b; Hogg et al. 2015). However, Gibbs et al. (2014a) warn of the inaccuracy of the data they use, as these originate from old, intransparent literature. Moreover, these studies do not describe the method of calculation, and it was not possible to gain more information here.

Anyway, by meeting the circular economy targets the European Commission aims at an increase of over 170,000 direct jobs in the waste management sector by 2030 (EC, 2015). These calculations and figures are criticized as fuzzy by Tamma \& Hervey (2018).

For Austria, our country of focus, employment figures in waste management are also sparse and imprecise: To date, employment figures in the waste sector have been compiled on the basis of various statistics and rough estimates. Weingärtler (2009) assumed an approximate number of 27,000 employees in waste management to be 
appropriate for the year 2005. The current Federal Waste Management Plan 2017 estimates the number of employees in the waste industry around 40,000 (BMNT, 2017). In both cases, there is no information available on how these estimates were retrieved.

To fill this gap at least partially, our paper takes a closer look at the Austrian mixed municipal ("residual") waste sub-sector. The primary aim is to show the personnel potential in the area of residual waste treatment in Austria. Through an orientation towards the circular economy - by means of improvements already at the collection stage - it is shown that this also increases the number of jobs. Thus, jobs can be generated in addition to the conservation of resources.

The primary focus is on how the various recovery or disposal methods affect direct employment. Hence, we investigate the following hypothesis:

The more differentiated the collection and treatment system of municipal waste, the higher the required number of employees and thus of jobs provided.

On this hypothesis we build our central research question:

- What is the direct employment potential in the area of residual waste treatment?

- split into several sub-questions:

- What employment level do the individual models require?

- What influence does the collection of residual waste or separately collected waste materials have on the employment effect?

- By what factor does the employment level of the individual models change compared to the basic model?

To test this assumption and answer the research questions, we model and compare different waste management models. To this end, the individual treatment steps or plants are assigned employment coefficients that we derive from data generated by means of data triangulation. By the aid of the coefficients and based on a normalized system input of 100,000 t per year, we calculate the respective accumulated employment effect of each model and compare the results. The rather idealized and simplified models give an estimate of the extent of the number of jobs created by a shift from one model to the other.

Within the framework of this research, we consider the following models for which we derive distinct changes in employment for collection and treatment:

- model 1: Unregulated landfilling [UL]

- model 2: $100 \%$ waste incineration [WI]

- model 3: Mechanical-biological treatment (MBT)

- model 3.1: MBT + incineration [MI]

- model 3.2: MBT + incineration + cement plant [MIC]

- model 3.3: MBT + cement plant [MC]

- model 3.4: MBT with dry stabilisation + incineration + cement plant [MDIC]

- model 4: Improved separate collection

- model 4.a: Improved separate collection according to the Benchmark-Study (Brunner et al. 2015) [ISCa] - model 4.b: Improved separate collection according to Best-Practice Vorarlberg [ISCb]
The current Austrian situation is reflected in model 2 with 100 percent incineration, which we use as a reference for comparing the other models. In improved separate collection (models 4.a and 4.b), a part of the residual waste stream is shifted to the recyclables collection. The goal here is to increase the quality and quantity of the material going into recycling (Kranzinger, Schopf, Pomberger, \& Punesch, 2017). We supposed from the outset that the model of improved separate collection can help to multiply the number of direct jobs by far in comparison to the other models. We had, however, only vague ideas on the effect on indirect employment effects and the effects induced by a shift between our models. Thus, we invited the Austrian Institute of Economic Research (WIFO, Meyer \& Sommer 2019) to calculate indirect and induced employment effects and will present their results in short.

The structure of the paper is as follows: After the introductory section we present the methods of data collection including a short excursus to reuse. Next, we describe deriving and compiling the individual research models. The next section comprises the comparison of our models and their employment effects, amended by the results of the research on indirect and induced employment effects by the WIFO. The discussion of the results follows en suite and finally, we examine the results critically, determine limitations and the need for further research.

\section{METHODS OF DATA COLLECTION}

We started our research by collecting and calculating employment figures and transfer coefficients. This requires an extensive survey of waste collection and treatment in Austria as provided by the Austrian Federal Waste Management Plan (BMNT, 2017). Here, the average generation and composition of residual waste are calculated from the residual waste analyses of the individual federal provinces. However, data on employment, residual waste analyses or transfer coefficients of facilities are hardly available.

To generate meaningful transfer coefficients and employment related data for the models, we chose an empirical three-step method (Hug, 2015). We applied a mixed methods approach equally making use of qualitative and quantitative data collection methods and used data triangulation to increase the validity of the output (Döring and Bortz, 2016; Flick, 2011).

We started gathering the data by secondary research on the current state of research and discovered that very few data are available in literature. Accordingly, we investigated a large number of plant types by means of meticulously conducted interviews.

After establishing an initial contact by telephone, most of the interviews were conducted by telephone or by email. The survey guide consisted of unstructured open questions adapted to the respective locations and plants. The aim was to obtain figures for calculating the employment effect for an input of 100,000 t of waste per year. Quite often we only received approximate figures due to confidentiality - a reduction in quality that we accepted in order to obtain data at all. 
In total, we got data from 105 plant operators with sites from all provinces of Austria as well as three foreign sites were surveyed on the following treatment steps:

- waste collection and waste transport,

- landfill,

- waste incineration,

mechanical-biological treatment (MBT),

substitute fuel production (SFP),

- use of substitute fuels in cement plants,

sorting of light weight packaging,

plastics recycling,

composting,

wastepaper sorting,

waste glass processing,

scrap metal processing.

In the following chapters we will present how the data were compiled. As there is a huge employment effect of reuse not included in our models (due to the small share of reuse) we at least mention some of the potential contributions.

\subsection{Residual Waste Data}

The focus is on mixed municipal waste from Austria, for which there are clear differences in the per capita generation across Austria, ranging from $83 \mathrm{~kg}$ in Vorarlberg to $289 \mathrm{~kg}$ in Vienna (BMNT, 2017), as listed in Table 1.

The data from the Federal Waste Management Plan 2017 , which contains the inventory for the year 2015, was used as the starting point for the waste volume. In addition, each federal province has records on the volume of residual waste and carried out residual waste analyses. Table 2 shows the analyses of the federal states used for the calculation.

We freed the residual waste analyses from any inconsistencies in accordance with the guidelines for the preparation of residual waste analyses (BMLFUW, 2017) and could then divide the residual into its main fractions (Figure 1).

Gaining data on improved separate collection (for models 4.a and 4.b) has to start as early as in households with the separation into the individual collection fractions. To this end, we chose two different approaches: On the one hand and in accordance with the "Benchmarking für die österreichische Abfallwirtschaft" (Brunner et al., 2015) we applied the assumption of a $50 \%$ reduction from the baseline; on the other hand, we used the average residual waste volume of Vorarlberg as a best practice example (ÖÖl and $\mathrm{TBH}, 2012$ ). Table 3 shows the comparison between them and the Austrian average.

TABLE 1: Mixed municipal waste - generation by federal states in Austria

\begin{tabular}{l|c|c}
\hline Federal states & Generation [t] & Generation [kg/capita] \\
\hline Burgenland & 35,000 & 121 \\
\hline Carinthia & 97,300 & 174 \\
\hline Lower Austria & 230,900 & 141 \\
\hline Upper Austria & 167,300 & 116 \\
\hline Salzburg & 93,300 & 172 \\
\hline Styria & 155,900 & 127 \\
\hline Tirol & 96,600 & 132 \\
\hline Vorarlberg & 31,800 & 83 \\
\hline Vienna & 523,500 & 289 \\
\hline Austria & $1,431,600$ & 166 \\
\hline
\end{tabular}

Table based on BMNT, 2017, p. 51

TABLE 2: Selected residual waste analyses from the federal states of Austria with study year and source.

\begin{tabular}{|c|c|c|}
\hline Federal states & Year & Source \\
\hline Burgenland & 2010 & TB Hauer, 2010 \\
\hline Carinthia & 2011 & Amt der Kärntner Landesregierung, 2012 \\
\hline Lower Austria & 2011 & $\begin{array}{l}\text { Amt der Niederösterreichischen Landesre- } \\
\text { gierung, } 2011\end{array}$ \\
\hline Upper Austria & 2013 & BMLFUW, 2015 \\
\hline Salzburg & 2007 & $\begin{array}{l}\text { Amt der Niederösterreichischen Landesre- } \\
\text { gierung, } 2011\end{array}$ \\
\hline Styria & 2014 & BMNT, 2017 \\
\hline Tirol & 2009 & FHAanalytik und TB Hauer, 2010 \\
\hline Vorarlberg & 2012 & ÖÖl und TBH, 2012 \\
\hline Vienna & 2016 & Stadt Wien, 2016 \\
\hline
\end{tabular}

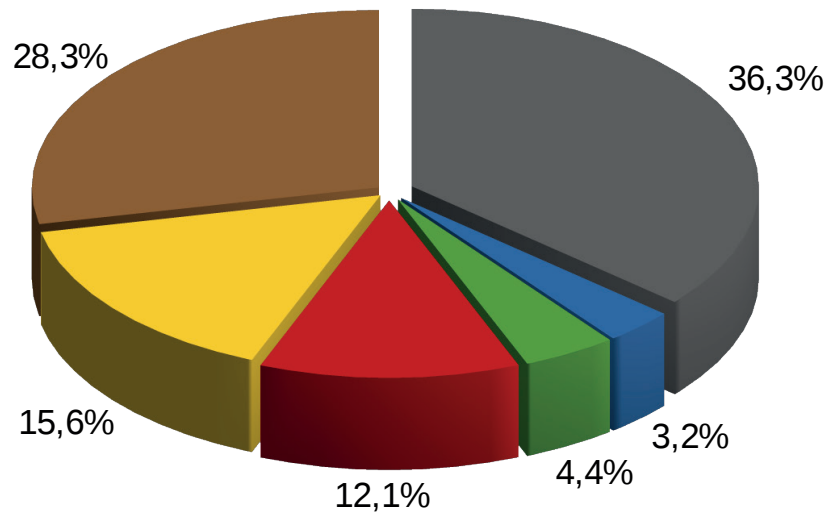

organic waste - lightweight packaging - paper, cardboard waste glass

scrap metals others

FIGURE 1: Splitting of fractions into main groups and percent per mass. 
TABLE 3: Comparison of the collection fractions - Austrian average with benchmark study and best practice Vorarlberg

\begin{tabular}{|c|c|c|c|}
\hline Collection system & Austrian average & Benchmark Study & Best Practice Vorarlberg \\
\hline collection of residual waste & $100.0 \%$ & $66.7 \%$ & $54.7 \%$ \\
\hline collection of lightweight packaging & $0.0 \%$ & $8.1 \%$ & $10.4 \%$ \\
\hline collection of organic waste & $0.0 \%$ & $14.6 \%$ & $20.0 \%$ \\
\hline collection of wastepaper & $0.0 \%$ & $7.0 \%$ & $9.9 \%$ \\
\hline collection of waste glass & $0.0 \%$ & $2.3 \%$ & $3.2 \%$ \\
\hline collection of scrap metals & $0.0 \%$ & $1.3 \%$ & $1.8 \%$ \\
\hline total & $100.0 \%$ & $100.0 \%$ & $100.0 \%$ \\
\hline
\end{tabular}

\subsection{Waste Collection and Transport}

The first step to be considered is waste collection, on which data proved to be difficult to obtain. This was due to a lack of literature and the lacking willingness and ability of companies to provide data. Furthermore, a plethora of influencing factors like container size, the ratio of drivers and loaders, collection intervals or the collection logic made a standardization impossible, as they can differ even at the levels of individual municipalities.

Accordingly, we assumed that the collection of residual waste is carried out in a pick-up (collection) system. A pickup system is furthermore also assumed for the models of improved separate collection, the collection of lightweight packaging, biogenic waste and wastepaper. Only for waste glass and scrap metals we adopted bring-it-yourself systems, with households bringing the pre-separated material to waste collection points. The respective employment effect calculated for each fraction is shown in Table 4.

As for transport between the individual plants, we could not determine secondary references and information from the interviews on neither the related employment nor the transport routes, only some isolated information is available as to environmental impacts (Frischenschlager et al. 2010). We discussed the values with an expert and had to accept a set of simplifying assumptions.

We assumed that all transports are carried out by truck, although in reality, the distances are also covered by rail. We reduced the load weight to three sizes and divided the estimated transport routes into $50 \mathrm{~km}$ intervals. Finally, we reduced the loading and unloading times as well as the regional and supraregional travel times to half-hourly intervals (Altendorfer, 2018). Table A.1 in the appendix contains the values for the loading weight, the transport routes and the employment per 100,000 $t$ for the transport routes used.

TABLE 4: Selected employment effects for the collection in the models.

\begin{tabular}{l|c}
\hline Collection system & Employees \\
\hline per 100,000 t & $100.0 \%$ \\
\hline collection of residual waste & 90.0 \\
\hline collection of lightweight packaging & 200.0 \\
\hline collection of organic waste & 90.0 \\
\hline collection of wastepaper & 70.0 \\
\hline collection of waste glass & 24.0 \\
\hline collection of scrap metals & 200.0 \\
\hline
\end{tabular}

\subsection{Waste Treatment Plant Data}

Gaining data on the employment of waste treatment plants also proved to be difficult. Literature only yielded information on sub-areas ranging from the negative impacts of unregulated landfilling to alternatives like waste incineration, co-incineration, MBT or substitute fuel production, but not on the employment required for these treatment methods. Reprocessing plants nearly go unnoticed in literature, except for the economic efficiency of recycling or the effects on the environment. An overview of waste treatment facilities in Austria is provided in the Federal Waste Management Plan, and also the homepage of the Association of Austrian Waste Management Companies (VOEB, 2017) offers an extensive list of members, which is useful for identifying relevant facilities. Our own survey also proved difficult as most of the interviewees could not reveal confidential data or lacked the time to compile the data. Again, we consulted with experts in the field and finally, with the information content still limited, we were able to calculate plausible values for the impact of different waste management models on employment. Into our models, we again integrated only direct jobs. These are summarized in Table 5. A detailed elaboration can be found in Altendorfer (2018).

\subsection{The Employment Approach}

In this paper we relate to the direct employment effects as in additional direct jobs of different waste management models. This is to mean that we look at full-time equivalents of people working in the waste residual waste related system, in transportation, sorting, preprocessing and treatment itself, but not in the downstream recycling process itself. The respective system boundaries will be explained in detail where necessary. Not part of our study, but of a subsequent study by the WIFO (Meyer \& Sommer 2019) were the indirect and induced effects on employment.

"Indirect effects" or upstream effects include the production of all intermediate inputs necessary for the direct activities. The corresponding data are abstracted in a socalled input-output matrix as intermediate inputs. "Induced effects" relate to the reactions of private households concerning consumption that are to be expected due to changed incomes and are calculated on the basis of an average propensity to consume (Meyer \& Sommer, 2019).

\subsection{Implications of Reuse}

Although the reuse sector is not included in the mod- 
TABLE 5: Selected employment effects for the treatment facilities in the models

\begin{tabular}{|c|c|c|}
\hline Abbreviation & Plant designation & Employees per $100,000 t$ \\
\hline Cem & waste co-incineration plant with rotary kiln in the cement plant & 4.0 \\
\hline Comp & composting plant & 35.0 \\
\hline GI-S & waste glass sorting plant & 10.0 \\
\hline $\mathrm{Gl}-\mathrm{T}$ & waste glass transfer station & 3.0 \\
\hline L-Shr & large shredder plant & 40.0 \\
\hline LF-D & domestic waste landfill & 5.0 \\
\hline LF-M & mass waste landfill & 10.0 \\
\hline LF-R & residual waste landfill & 10.0 \\
\hline LWP-S & lightweight packaging sorting plant & 200.0 \\
\hline MBT & MBT plant & 18.0 \\
\hline MBT-dry & MBT plant with dry stabilisation & 18.0 \\
\hline Met-T & scrap metal transfer station & 3.0 \\
\hline P-Shr & post shredder plant & 150.0 \\
\hline PAP-M & wastepaper sorting plant & 25.0 \\
\hline Pla-R & plastic recycling plant & 200.0 \\
\hline SFP-P & substitute fuel production plant & 16.0 \\
\hline WI-F & waste incineration plant with fluidised bed combustion & 22.0 \\
\hline WI-G & waste incineration plant with grate firing & 24.0 \\
\hline
\end{tabular}

els as it for a bigger part occurs outside the waste regime, reuse offers an enormous potential for jobs in the area of waste avoidance. What used to be a common practice of repairing things and putting them back into operation has almost completely disappeared in recent times. However, to some extent there has been a paradigm shift, and in recent years the quantities of goods collected for preparation for reuse have increased and are now at about $0.1 \%$ of the total Austrian volume of municipal waste from households and similar establishments. An increase to $1 \%$ is a realistic assumption, as the example in Flanders shows (Neitsch \& Wagner, 2017). Even though the amount of waste diverted from the waste stream is very small, it has a large impact on employment effects. Processing, sorting, cleaning and refurbishing are very labor-intensive processes requiring a high amount of manpower which not necessarily has to be well-skilled. This leads to another special feature of the reuse sector: Reuse companies feature a unique personnel structure by providing transit training jobs for people furthest from the labor market, permanent jobs for people with special needs and opportunities for voluntary work (Neitsch \& Wagner, 2017). According to them, the potential number of jobs in the reuse sector ranges from 4,000 to 7,500 per 100,000 t of reuse material.

\section{DERIVING THE MODELS}

From the data compiled we derived our waste management models that depict treatment paths in a simplified way. These do not claim to represent reality exactly but show a sequence of the waste stream concentrated on the fundamentals. Due to the complexity and the large regional differences, a real representation of waste management is hardly possible. But although in reality mostly combinations of several of the ideal-typical models will be found and small regional deviations are possible, we are convinced that the material flows and personnel coefficients meet the actual situation in Austria very well.

We devised four different models for the comparison of waste management systems. The analysis starts with collection and ends either with landfilling, in facilities where the end of waste is reached or before the recycling process takes place. In each model we trace an input of 100,000 t through each step. In models 1 to 3 , this amount is directly distributed to the various treatment plants. Only in model 4, a part of the residual waste already attains the recyclables collection at the waste producer, from where it is sent to the different recycling processes. Collection is considered a subsystem that is required throughout the whole process but is excluded as a basic collection in the comparison of the models, as this procedure is indispensable for each model. Furthermore, the employment effects are broken down into people working in the facilities and transport. On this basis, we calculate the respective required employment for each treatment step including collection and transport and subsequently sum up the number of employees for the entire model.

\subsection{Model 1: Unregulated Landfilling}

In this model, the entire volume is brought untreated to a nearby unregulated domestic waste landfill (see Figure 2), a method that has been prohibited in Austria since the Landfill Ordinance of 2004 where a treatment prior to landfilling is required in order to reduce the amount of total organic carbon contained in the waste. We still chose to include this model, as it is still common practice in European countries such as the Czech Republic, Bulgaria or Romania. 


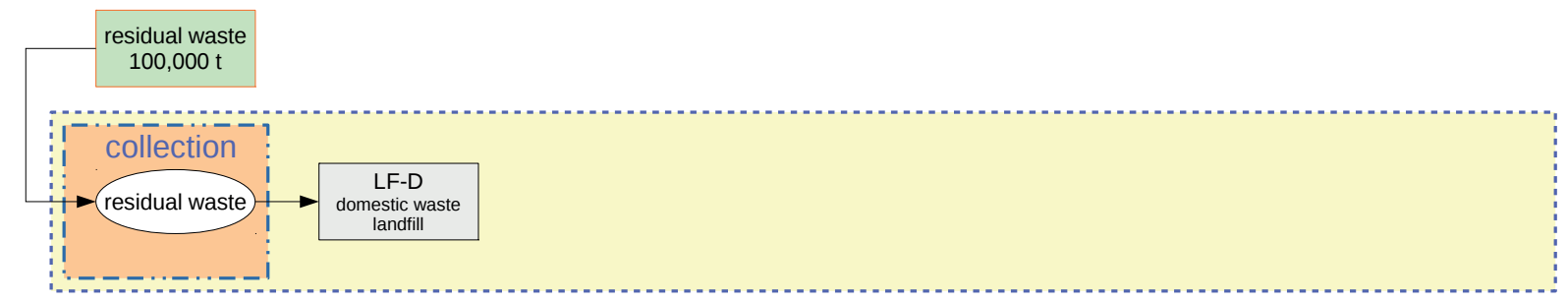

FIGURE 2: Model 1 - Unregulated landfilling.

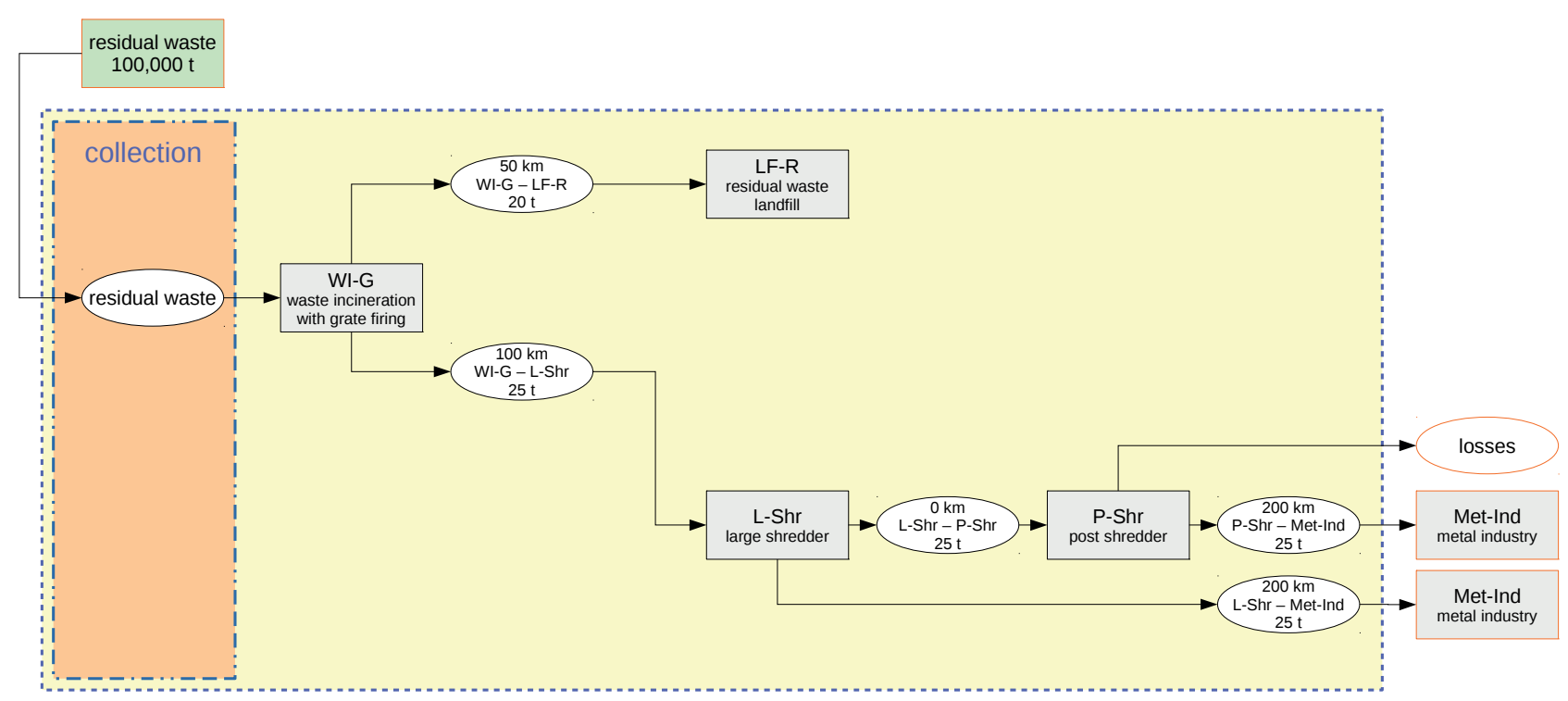

FIGURE 3: Model 2 - $100 \%$ waste incineration.

\subsection{Model 2: $100 \%$ Waste Incineration}

Contrary to model 1 , in model 2 all residual waste is directly brought to a waste incineration plant with grate firing. These plants are capable of directly incinerating the untreated waste. Residues of incineration go to a residual waste landfill. These residues (ash, dust, ...) still contain a small amount of metals, which are separated from the landfill fraction and fed into the metal recycling process (Figure 3).

\subsection{Model 3: MBT}

In model 3 , the collected residual waste is first brought to a MBT plant (MBT). Depending on the type of plant, it can produce different qualities and quantities of high-calorific value fractions and landfill fractions. Accordingly, we divided model 3 into four sub-models:

- model 3.1 MBT + incineration

- model 3.2 MBT + incineration + cement plant

model 3.3 MBT + cement plant

- model 3.4 MBT with dry stabilization + incineration + cement plant

Models 3.1 to 3.3 use the identical type of MBT. However, the output is utilized in different ways. MBT with dry stabilization attempts to produce a maximum proportion of the high-calorific fraction and is included in model 3.4. The next sections describe models 3 in more detail.

\subsubsection{Model 3.1: MBT plus Incineration}

In model 3.1 the entire medium-caloric fraction and high-calorific fraction (about 60\%) from the MBT goes to a waste incineration plant with fluidized bed firing. The residues remaining there are brought to a residual waste landfill. Material which features a calorific value too low for thermal recovery is sent to a mass waste landfill for final disposal. During processing in the MBT, iron scrap can still be separated as a secondary material. To this end, the fraction is sent to a large shredder plant and a subsequent post-shredder plant, where the processing and sorting into metals and non-ferrous metals takes place. Transporting the scrap metal to a metal processing plant to the metal industry is still inside our system boundaries and hence included in our calculation. The employment requirements and the related expenditure in the metal industry, however, are outside of our system boundaries (Figure 4).

\subsubsection{Model 3.2: MBT plus Incineration plus Cement Plant}

Model 3.2 features one main difference to model 3.1, that is the destination of the high-calorific fraction in the cement industry and the use of the medium-calorific fraction for waste incineration in a fluidized bed incinerator. The residues from the fluidized bed combustion are again sent to a residual waste landfill. For use in the cement industry, the high-calorific fraction is processed in substitute fuel production plants in such a way that it can be added 


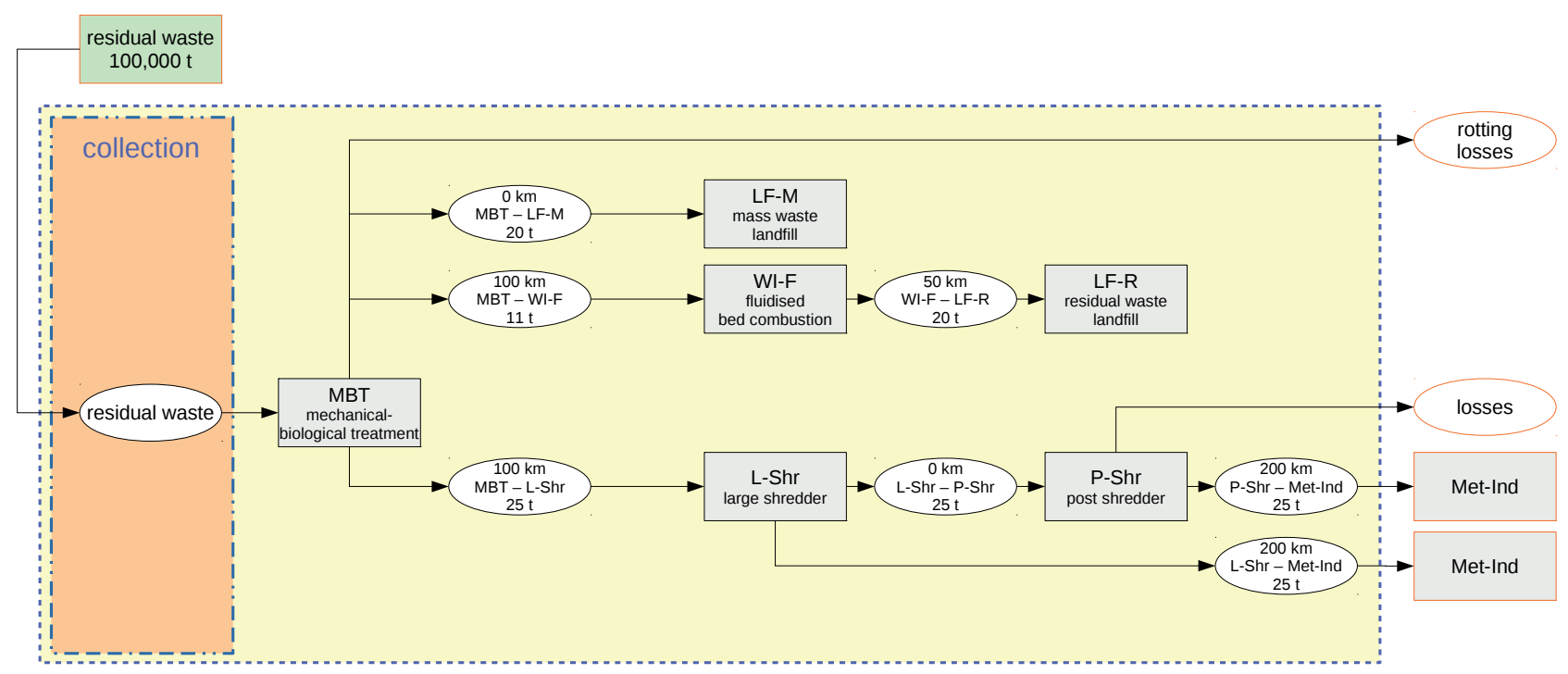

FIGURE 4: Model 3.1 - MBT + incineration.

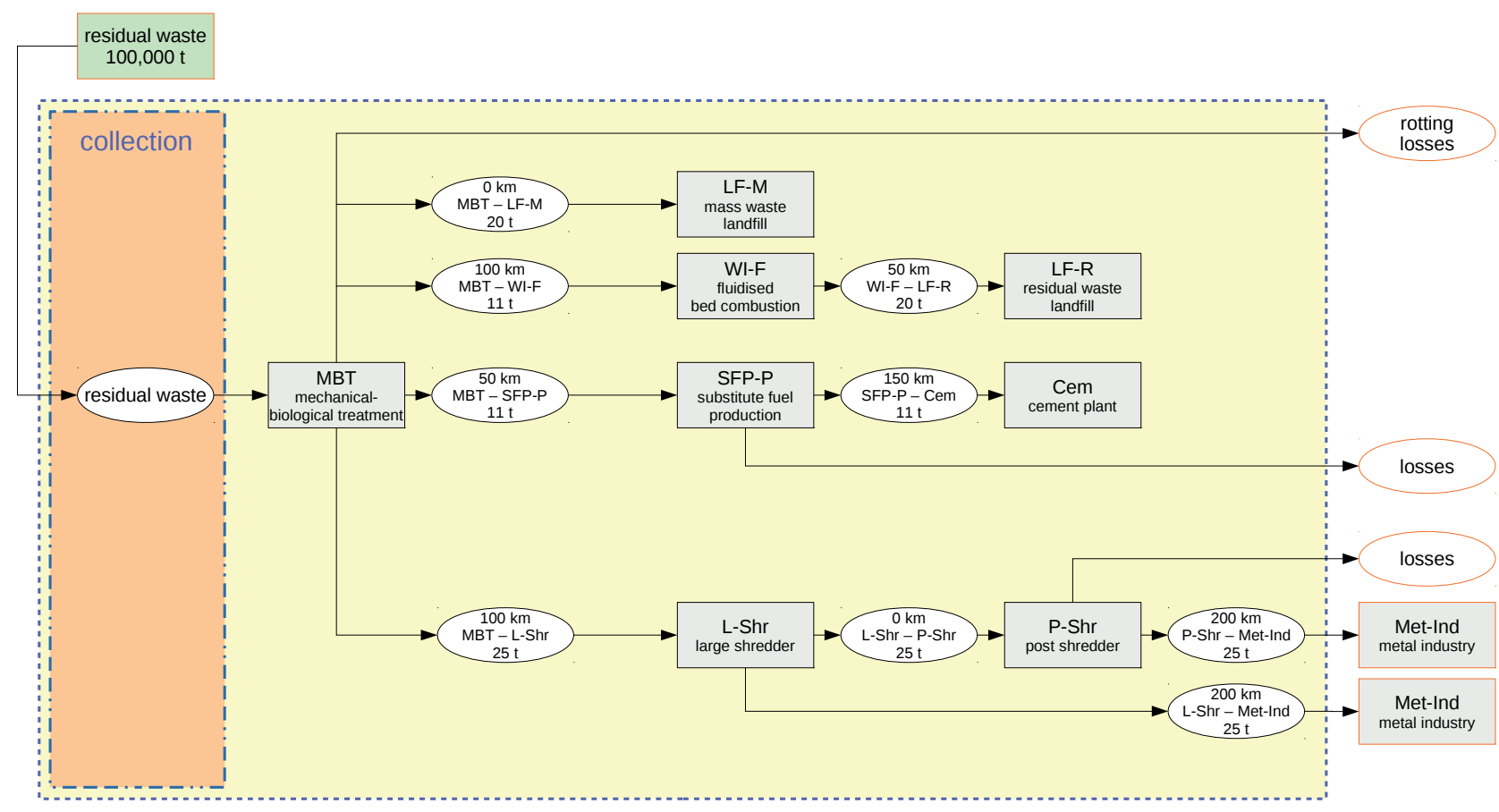

FIGURE 5: Model 3.2 - MBT + incineration + cement plant.

to the rotary kiln as a substitute for fossil fuels. Since no residues remain when waste is incinerated in the cement plants, our calculation ends here. Material which features a calorific value too low for thermal recovery is again sent to a mass waste landfill. As in the previous model, scrap metal is discharged from the MBT and processed in shredder plants for the recycling process in the metal industry (Figure 5).

\subsubsection{Model 3.3: MBT plus Cement Plant}

In model 3.3 both medium-calorific and high-calorific fractions are fed into the cement production process. The processing of the high-calorific material takes place as described in model 3.2 in a plant for substitute fuel production. The main difference is that only a small amount remains to be landfilled, as the material is caught up in the cement kiln (Figure 6). The landfill fractions from the MBT go to a mass waste landfill as described above and the scrap metals are also treated as in the previous models.

3.3.4 Model 3.4: MBT with Dry Stabilization plus Incineration plus Cement Plant

Model 3.4 involves MBT with dry stabilization. Here, the percentage of rotting losses and the residues for depositing in mass waste landfills can be reduced and a 


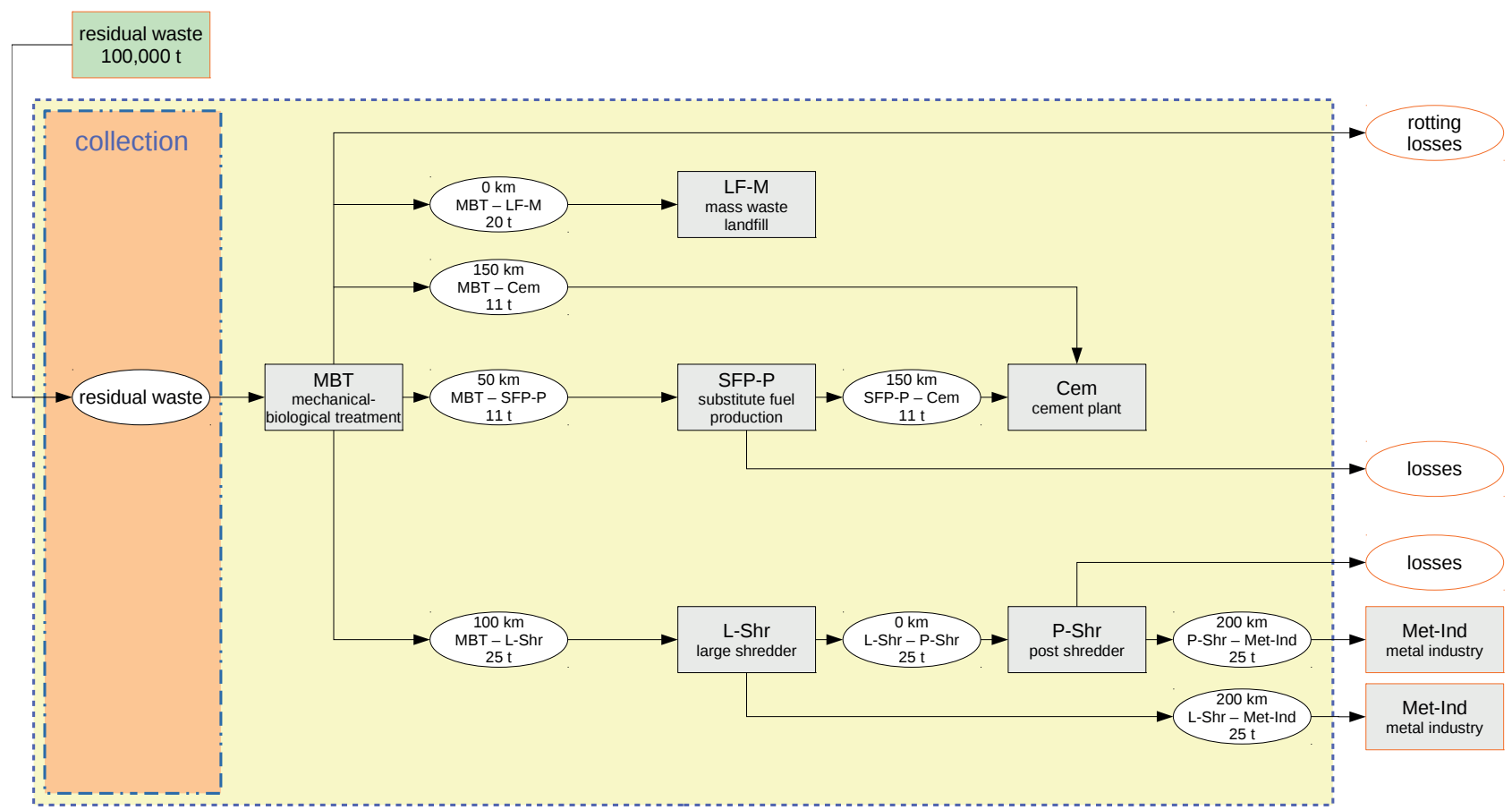

FIGURE 6: Model 3.3 - MBT + cement plant

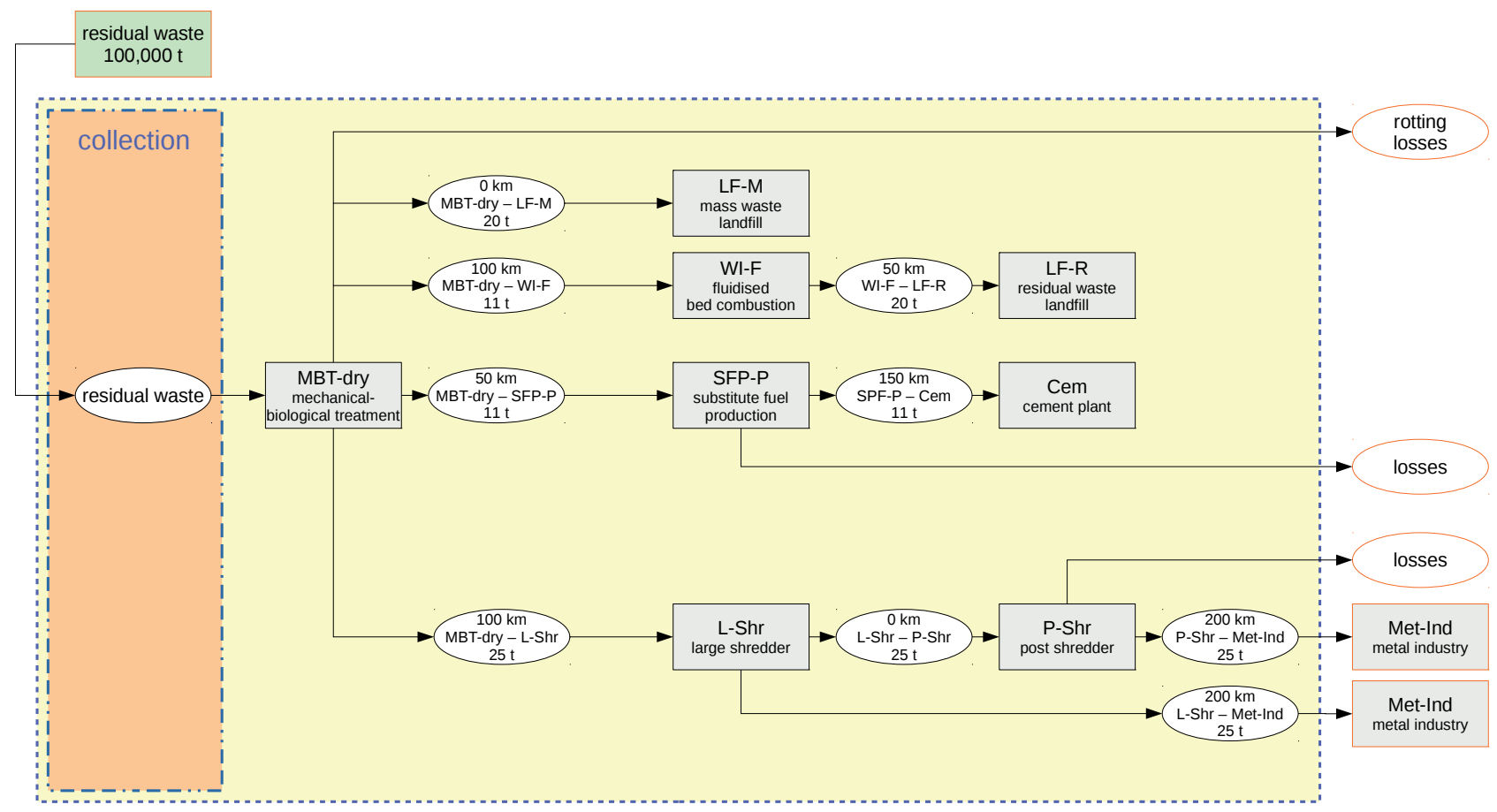

FIGURE 7: Model 3.4 - MBT with dry stabilization + incineration + cement plant.

considerably larger part of a thermally recoverable fraction is produced. Almost $60 \%$ of the high-calorific material is transported to plants with fluidized bed combustion (Figure 7), as in model 3.2.

The other part is sent to a substitute fuel production plant for conditioning and then to the cement plants. Again, scrap metal is discharged as in the other MBT models and processed for the metal industry.

\subsection{Model 4: Improved Separate Collection}

This model stipulates improved separate collection already at the household and hence the collection levels, as in the previous model for an input of $100,000 \mathrm{t}$. The main difference is the division of the input into further waste streams in addition to the residual waste fraction. Two different sub-models are presented for this purpose. 
- Model 4.a: Improved separate collection according to benchmark study (Brunner et al. 2015)
Model 4.b: Improved separate collection according to Best Practice Vorarlberg (ÖÖI \& TBH 2012)

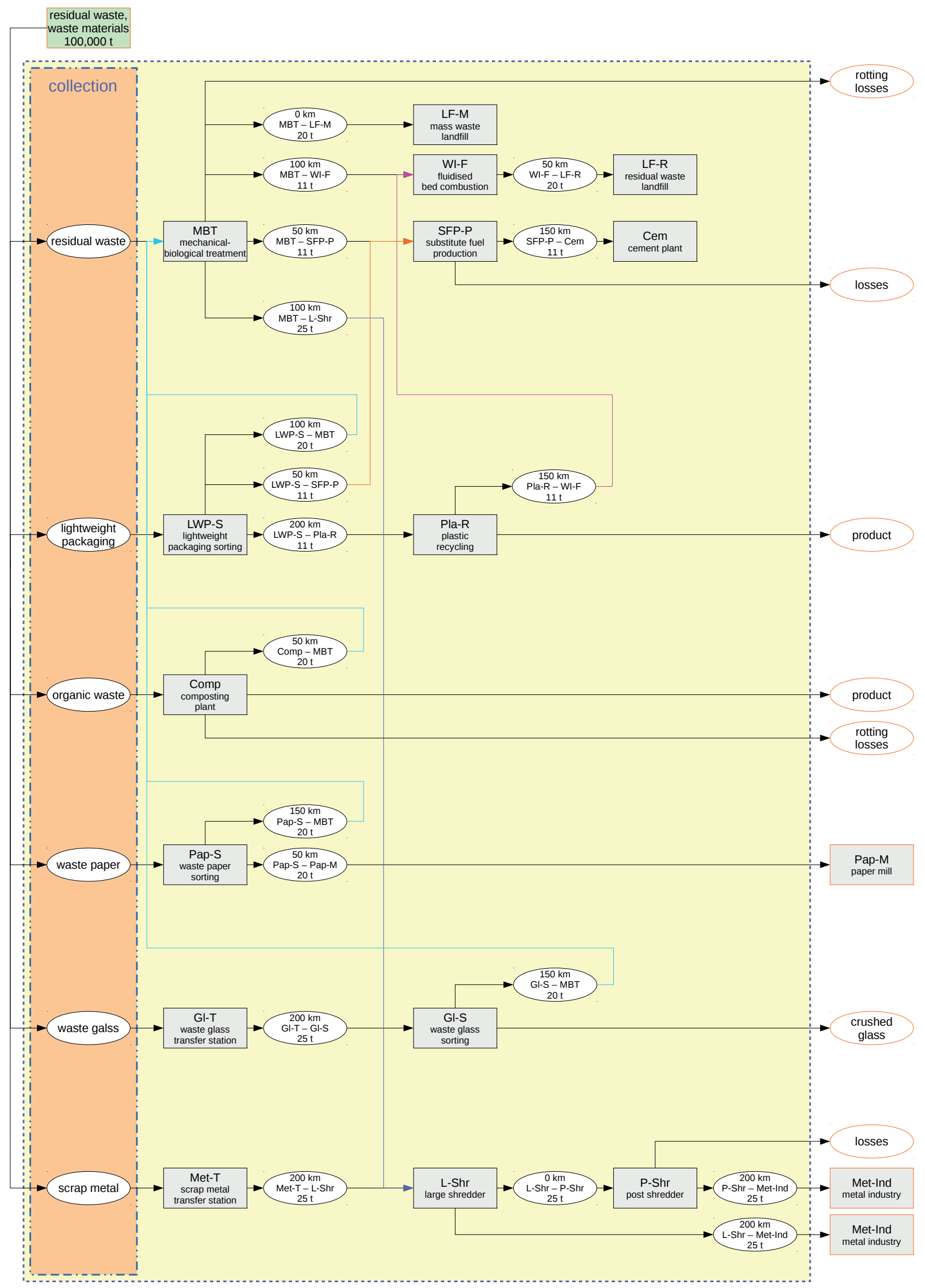

FIGURE 8: Model 4 - Improved separate collection. 
Collection is basically provided in a pick-up system, only the fractions "wastepaper" and "waste metals" are collected in a bring-it-yourself system at waste collection points. By now considering six different material flows, this model features the greatest complexity (Figure 8). Similar to the collection and the different treatment stages for residual waste in the other models, the models require even more simplifications for the other waste fractions. We will describe these in the following. It has to be mentioned that labor in households (e.g. for separating) remains uncompensated for and is thus not included in our models.

- Residual waste: The processing of the residual waste equals model 3.2. After MBT, the low-calorific part goes directly to landfill, the medium-calorific part to fluidized bed incineration and the high-calorific part, after processing in a substitute fuel production plant to the cement industry.

- Lightweight packaging (LWP): The fraction of lightweight packaging separated at household level is collected there in a pick-up system and brought to a sorting plant where recyclable plastic (e.g. PET) is sorted out and taken to plastic recycling plants. Our system boundaries end with the input into the production of plastic granulate or plastic flakes, as the granulate is no longer a waste and most production facilities for recycling plastic are not located in Austria. However, the much bigger part of lightweight packaging cannot be reintroduced into the cycle and thus goes to SFP production. Due to the high-calorific value of plastic, the cement industry is a major customer for this waste product.

- Organic waste: Residual waste contains a significant amount of biogenic waste falsely inserted there. Reducing the amount of misdirected organic waste and providing organic waste bins nationwide can create a significant reduction of residual waste and a large organic waste material flow. This material is processed in composting plants, which produce compost soil in various rotting stages. Since compost constitutes an end of waste, it is thus outside the considered system.

- Wastepaper: Wastepaper collection is one of the oldest and best-known collection services in Austria. After collection, the wastepaper is sent to a sorting plant where large contaminants are sorted out. Pressed into bales, the wastepaper comes to the paper mill where it is fed into the recycling process. The consideration of the wastepaper stream ends with the delivery to the paper mill. Processes such as de-inking are no longer considered within the system boundaries.

- Waste glass: Like wastepaper waste glass has been inserted into recycling processes in Austria for several decades. Collection is mainly provided in a bringit-yourself system at waste collection points. The collected waste glass is taken to a transfer station and from there transported to the waste glass sorting plants. These sorting plans are usually located directly at or in the vicinity of glass producers. Therefore, the system boundary is drawn directly after the waste glass sorting plant.
- Scrap metals: The collection of scrap metals at waste collection points is very similar to that of waste glass. From the transfer station the material is transported to the metal sorting plants. The process is analogous to the previous models. In the first step, processing takes place in large shredder plants. Ferrous metals are sold to the metal industry as recyclable material. Non-ferrous metals are further processed at the same site to subsequently be sold to the metal industry.

We will next describe the two models in this respect.

\subsubsection{Model 4.a: Improved Separate Collection According to} the Benchmark Study

To compile model 4.a, we referred to scenario R2 (resource conservation) in the "Benchmarking für die österreichische Abfallwirtschaft" (Brunner et al. 2015). Table 3 shows a comparison of the individual collection fractions in percent. For model 4.a, the remains in the residual waste collection add up to about $67 \%$. The remaining quantities of waste are dispersed among the collection of light packaging, organic waste, wastepaper, waste glass and waste metals.

\subsubsection{Model 4.b: improved separate collection according to Best Practice Vorarlberg}

Model 4.b is based on the results of the Vorarlberg residual waste analysis (ÖÖI \& TBH 2012). Table 3 compares the distribution of the individual collection streams to the baseline situation and the benchmark model. Due to a good separation of the recoverable waste, only about $55 \%$ of the residual waste remains.

\section{RESULTS - COMPARISON OF THE MO- DELS}

\subsection{Direct Employment Effects}

In this section we present the results of our research by comparing and contrasting the employment effects calculated according to the development of our models. Table 6 lists the resulting number of employees required for each model.

Collection is assumed to be comprehensive and thus considered separately by determining and calculating the number of staff required for collection for each individual model. On this basis, we compare the models to each other in order to obtain the ratio of employment between the individual models.

An increase in the number of staff required at the plants can be noticed already in model 2 . The additional employment is largely contributed by the waste incineration plant, and a small share of additional employment is due to transport. All models 3.1 to 3.4 involving a MBT plant as the first treatment step require roughly the same number of employees. Only in model 3.3, the number of employees in the plants is significantly lower than in the others, which can be explained by taking into account that running a cement plant on secondary instead of primary fuel does not require many additional staff and there is no landfill fraction remaining. In terms of transport, model 3.4 stands out with a value of 26.9 persons in comparison to models 3.1 
to 3.3. In model 3.4, there are lower quantities of residues going to mass waste landfill and lower rotting losses. Also, the share of high-calorific fractions and their processing increases, which subsequently also explains the increase in transports.

The improved separate waste collection in models 4 .a and $4 . b$ are obviously more labor-intensive. Interestingly enough, in model 4.b the effort in collection increases only marginally, although almost half of the residual waste is here collected among the recoverables. Neither is there an increase of the employment related to transport in comparison to models 3.1 to 3.4 . Visibly more employees, however, are needed in the plants.

At any rate, in all models, collection accounts for a sig- nificant part of the additional employment regardless of whether the residual waste goes to landfill or is treated in another facility. The number of staff necessary for residual collection in models 1 to 3 amounts to 90 jobs per 100,000 t of input. Only in the models 4 with improved separate collection the employment intensity increases slightly by 7.4 persons in model 4 .a and by 9.3 persons in model 4.b.

Thus, we use the number of 90 persons as a basic feature for the amount of staff required for collection. We therefore detract this number from the total number to scale the results. Only if the collection exceeds 90 persons, the surplus is included in our calculations and has an influence in the comparisons (Table 7 and Figure 9).

This scaling has the greatest influence on model 1

TABLE 6: Employment effects of all models per 100,000 t of input.

\begin{tabular}{|c|c|c|c|c|c|}
\hline & abbreviation & collection & plants & transport & total \\
\hline model 1 & UL & 90.0 & 5.0 & - & 95.0 \\
\hline model 2 & WI & 90.0 & 27.9 & 3.0 & 120.9 \\
\hline model 3.1 & $\mathrm{MI}$ & 90.0 & 35.6 & 18.3 & 143.9 \\
\hline model 3.2 & MIC & 90.0 & 34.7 & 21.5 & 146.2 \\
\hline model 3.3 & $\mathrm{MC}$ & 90.0 & 26.6 & 22.8 & 139.4 \\
\hline model 3.4 & MDIC & 90.0 & 38.5 & 26.9 & 155.4 \\
\hline model 4.a & ISCa & 97.4 & 56.4 & 20.2 & 174.0 \\
\hline model 4.b & ISCb & 99.3 & 62.5 & 19.5 & 181.3 \\
\hline
\end{tabular}

TABLE 7: Employment effects - model comparison per 100,000 t of input (without basic collection).

\begin{tabular}{|c|c|c|c|c|c|}
\hline & abbreviation & collection & plants & transport & total \\
\hline model 1 & UL & - & 5.0 & - & 5.0 \\
\hline model 2 & WI & - & 27.9 & 3.0 & 30.9 \\
\hline model 3.1 & $\mathrm{MI}$ & - & 35.6 & 18.3 & 53.9 \\
\hline model 3.2 & MIC & - & 34.7 & 21.5 & 56.2 \\
\hline model 3.3 & $\mathrm{MC}$ & - & 26.6 & 22.8 & 49.4 \\
\hline model 3.4 & MDIC & - & 38.5 & 26.9 & 65.4 \\
\hline model 4.a & ISCa & 7.4 & 56.4 & 20.2 & 84.0 \\
\hline model 4.b & ISCb & 9.3 & 62.5 & 19.5 & 91.3 \\
\hline
\end{tabular}

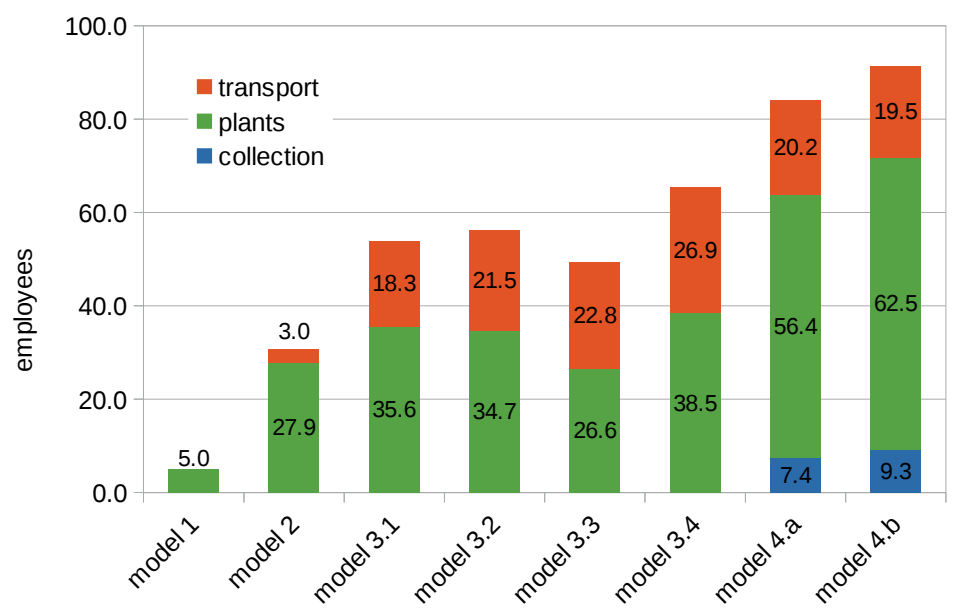

FIGURE 9: Comparison of employment of the models (without basic collection). 


\begin{tabular}{|c|c|c|c|}
\hline & \multicolumn{3}{|c|}{ Ratio } \\
\hline & Abbreviation & Base model 1 & Base model 2 \\
\hline model 1 & UL & 1.0 & 0.2 \\
\hline model 2 & WI & 6.2 & 1.0 \\
\hline model 3.1 & MI & 10.8 & 1.7 \\
\hline model 3.2 & MIC & 11.2 & 1.8 \\
\hline model 3.3 & MC & 9.9 & 1.6 \\
\hline model 3.4 & MDIC & 13.1 & 2.1 \\
\hline model 4.a & ISCa & 16.8 & 2.7 \\
\hline model 4.b & $\mathrm{ISCb}$ & 18.3 & 3.0 \\
\hline
\end{tabular}

since here the employment is almost exclusively bound in collection.

To allow for a better comparability, we define two base models on the basis of employment figures calculated above:

- base model 1: Unregulated landfilling

- base model 2: $100 \%$ waste incineration

and normalize each base model to the baseline of 1 . According to this frame of reference we calculate to which extent the employment effect for the other models differs (Table 8).

\section{Base Model 1: Unregulated Landfilling}

Base model 1 is built on the (for more sophisticated waste management systems) unrealistic assumption that all residual waste goes to landfill without any other treatment. It shows that even with model 2 the employment increases by a factor of more than six. The processing of the residual waste in an MBT (models 3 ) increases the employment effect compared to base model 1. from 9.9 (model 3.3) to 13.1 (model 3.4), with a significant contribution arising from transport.

With improved separate collection (models 4), the em- ployment effect is about 17 times higher than with unregulated landfilling. There is only a slight increase in the effort required for collection. Compared to models 3.1 to 3.4 , the employment figures for transport remain approximately the same or even decrease. The main reasons for the staff changes are up to in the facilities. Figure 10 shows the graphical representation of the individual models compared with model 1 as the baseline.

\section{Base Model 2: $100 \%$ Incineration}

Base model 2 is built on the assumption that all residual waste goes directly into incineration, which represents a very popular process for dealing with residual waste in Austria. Of course, the ratios of the individual models among each other remain the same, only the actual numerical values change due to the shift of the base to model 2 . When compared with the models applying MBT followed by incineration or co-incineration, employment increases by a factor of 1.6 to 2.1 (Figure 11). This is mainly due to transporting in between the plants. A switch from $100 \%$ waste incineration to improved separate collection and thus also a significant increase in the recycling rates causes an increase in the employment of about three times.

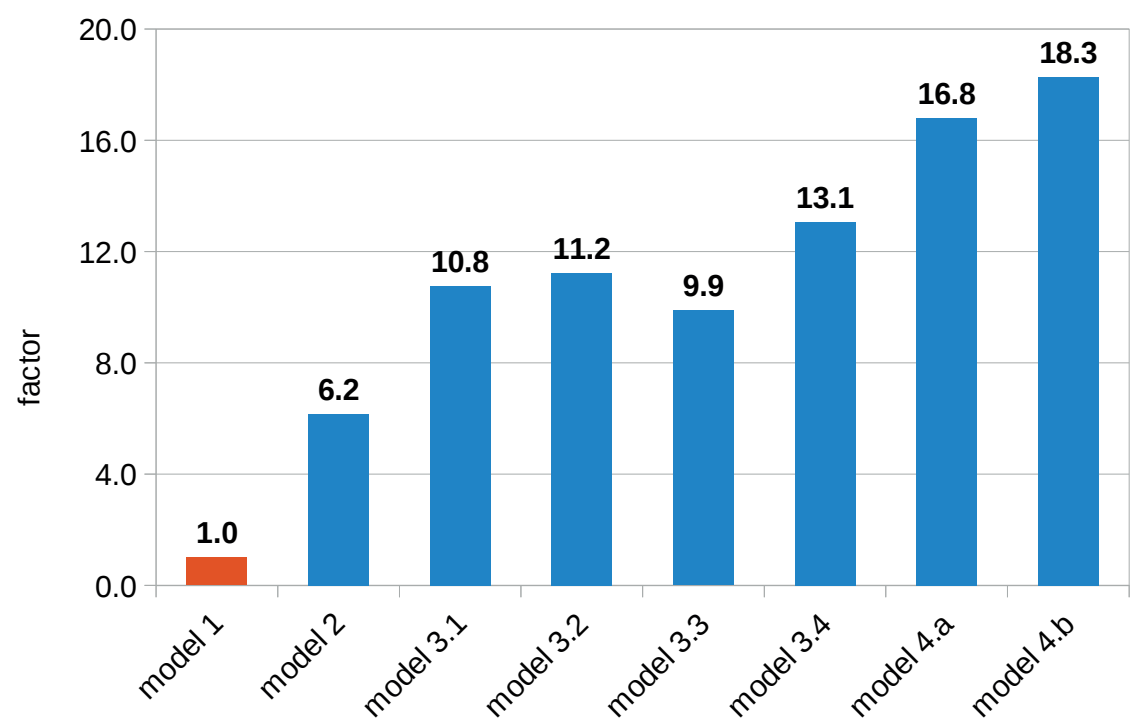

FIGURE 10: Factor comparison of the models (without basic collection): base model 1 . 


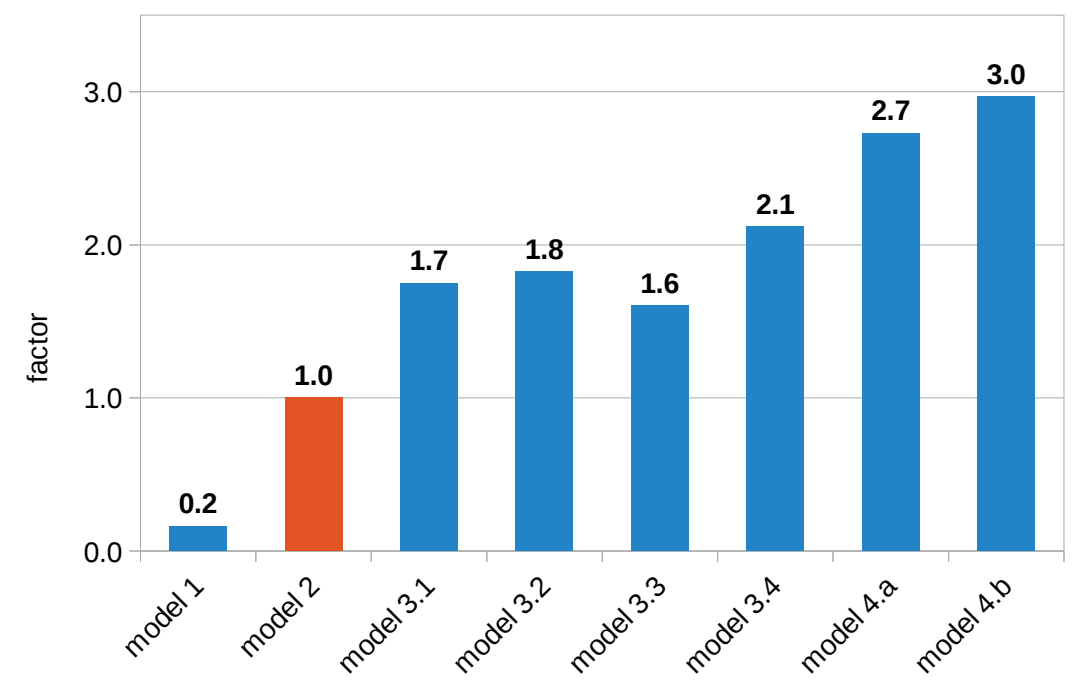

FIGURE 11: Factor comparison of the models (without basic collection): base model 2.

\subsection{Indirect and Induced Employment Effects}

Paradigm shifts in waste management do not only cause direct employment effects, but also induce indirect ones. The WIFO used our previous calculations and results to include the indirect and induced employment effects (Meyer \& Sommer 2019). For their calculation, they adapted the macroeconomic model WIFO.DYNC, a dynamic single-region and multi-sector model based on the revenue and expenditure tables of Statistics Austria. The results are differentiated into their direct, indirect and induced effects and include changes in added value, employment and energy demand (Meyer \& Sommer 2019).

As with the direct employment effects a more complex and costly residual waste treatment entails a higher demand for labor (Figure 12). Unlike our comparison of models, the WIFO comparison did not exclude employment required for collection. Thus, the highest result from their calculations is for model 4.b at 317 employees. model 2 features only 197 employees, the lowest number of all models (Meyer \& Sommer 2019).

\section{DISCUSSION}

In order to fulfil the aim of comparing potential employment effects in the field of residual waste treatment we developed a set of four different models, representing four basic stages of evolution in waste management and with the plants involved as the distinctive elements: Unregulated landfilling, $100 \%$ incineration, several combinations of MBT and additional methods and an improved waste sepa-

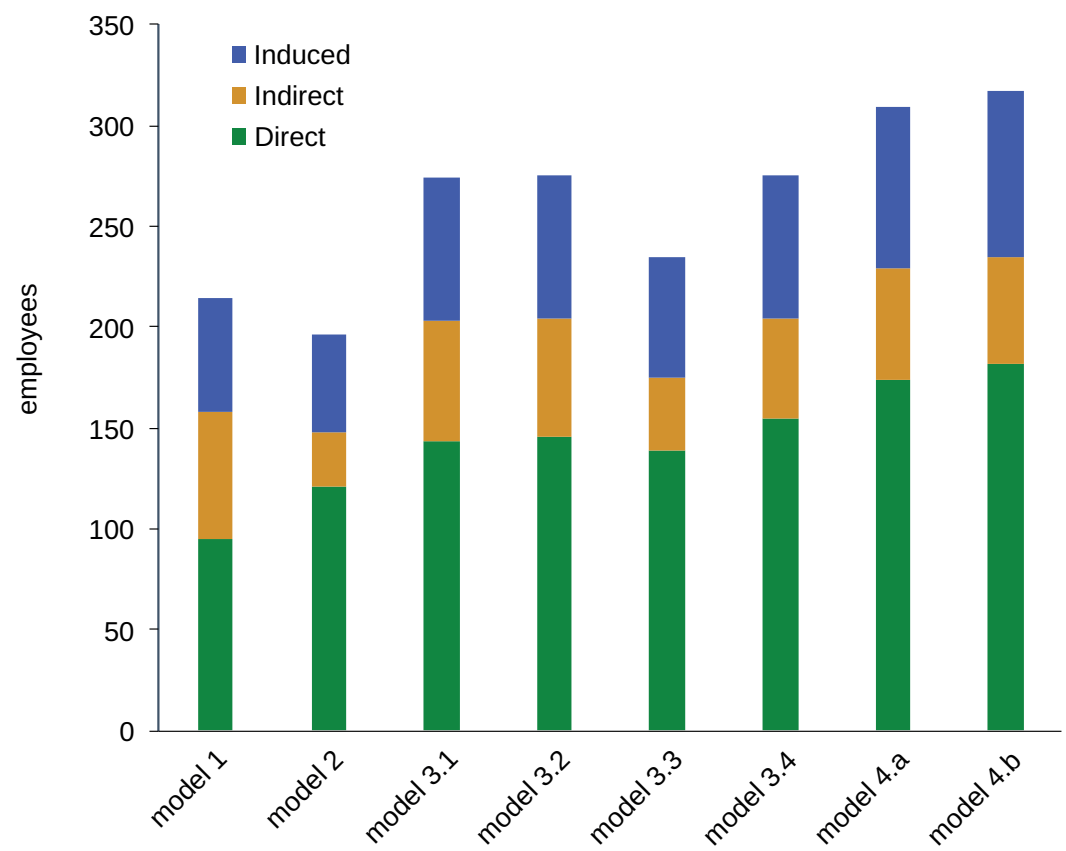

FIGURE 12: Employment effects including direct, indirect and induced effects (Meyer \& Sommer 2019). 
ration already at consumer level. In this respect, a variety of factors have a considerable influence on employment figures. These include the differences in waste composition, but also the sizes and operational structure of the plants as well as the further use of the output.

In order to compare the models properly, we designed them in a way that each of them ranged from collection and transport to processing in individual plants and was based on a standardized input quantity of $100,000 \mathrm{t}$ of residual waste. The average input was calculated from the residual waste analyses of the various provinces in Austria. In the two models of improved separate collection (models 4.a and 4.b), this input was also divided into different waste- and their respective recovery streams. The selected data and the models are of course simplified and the numerical results should be used with caution. However, they do show the enormous employment potential of sophisticated waste management approaches.

In the first step, the labor for an input of $100,000 \mathrm{t}$ was calculated for each individual model (Table 6). It also shows the employment figures for the collection. From this it can be seen that improved separate collection does not have a significant impact on the employment effect. The significant changes between the models are in the areas of facilities and transport. Since the collection causes approximately the same employment in all models, the fixed value of 90 persons for the "basic collection" is deducted for the factor comparison.

From an Austrian perspective, model 2 serves as a suitable base model. However, model $4 . b$ can be considered a realistic target. It is based on the residual waste volume of Vorarlberg and thus represents an already established situation. An improved waste management system provides an enormous potential for new jobs - compared to $100 \%$ waste incineration (model 2) even a tripling of the direct employment effect (Table 9). Additionally, this approach helps conserve finite resources as significantly more materials are recycled through better processing of the waste materials.

We detect the biggest difference of 86 jobs more between base model 1 and model 4.b, comparison of model 4.b with base model 2 still yields 60 more jobs. The results in detail are shown in Table 10.

Transferred to the real situation in Austria and thus to a basis of more than 1.2 million $t$ of residual and bulky waste directly sent to incineration in 2015 (BMNT 2017), a shift from model 2 to model 4.b would create 730 direct jobs (Table 11), a significantly higher recycling rate and further indirect employment effects. Projecting our results to EU level is of course sketchy, as systems and approaches throughout the EU differ as much as the level of automation and other external drivers. Conceding this restriction, based
TABLE 10: Combined factor comparison of the models (without basic collection)

\begin{tabular}{|c|c|c|c|}
\hline \multirow[b]{2}{*}{ target model } & \multirow[b]{2}{*}{ abbreviation } & \multicolumn{2}{|c|}{ compare models } \\
\hline & & model 1 [UL] & model 2 [WI] \\
\hline model 4.b & ISCb & 86.4 & 60.6 \\
\hline
\end{tabular}

growth in jobs per 100,000 t of input

TABLE 11: Potential additional jobs in full-time equivalents for Austria and the EU.

\begin{tabular}{l|c|c|c} 
& [UL] $\rightarrow$ [ISCb] & [WI] $\rightarrow$ [ISCb] & \\
\hline Austria & - & 730 & jobs \\
\hdashline EU & 51,000 & 40,000 & jobs \\
\hline values rounded & & &
\end{tabular}

on 66 million t of residual waste incinerated (Eurostat 2018) up to 40,000 additional jobs could be created. Assuming the 59 million $t$ of waste landfilled in the EU in 2016 (Eurostat 2018) going to unregulated landfilling this would create a potential of up to 91,000 new jobs at EU level.

A glance at re-use, which due to a lack of data, is not included in this work, shows that in this area of waste management the greatest employment effect could be skimmed. Hardly noticed, since the goods are only in the waste regime for a short time, waste prevention represents an enormous employment potential and value added, although only a small volume of waste is involved. With $100,000 t$, diverting only $1 \%$ of goods from the waste stream would mean an increase of about $40-75$ jobs.

Creating a realistic representation of all of Austria is impossible, as there are considerable differences at municipal levels and, even more importantly, there is a lack of employment-related figures in waste management. Models suitable for the individual consideration of a region or a municipality, including specifics like seasonal (e.g. tourism) or area-related aspects (e.g. urban or rural), will consist of a combination of the models created here and can be amended by adjusting the values or by taking into account diverse influence factors of residual waste separation, collection, and treatment.

Furthermore, the results and figures on employment effects obtained in this work constitute only one component of a large and very complex system and cannot be used as an exclusive basis for waste management decisions. To gain a holistic view of waste management, other system components must be taken into account in addition to employment effects. Thus, the models can serve as a starting point and be supplemented by additional factors such as:

- environmental impacts,

TABLE 9: Combined factor comparison of the models (without basic collection).

\begin{tabular}{|c|c|c|c|c|c|c|}
\hline & model 1 & model 2 & \multicolumn{3}{|c|}{ model 3} & model 4 \\
\hline & [UL] & [WI] & \multicolumn{3}{|c|}{ [MBT]* } & {$[$ ISC]** } \\
\hline factor & 1 & 6 & : & 11 & : & 18 \\
\hline factor & & 1 & : & 2 & : & 3 \\
\hline
\end{tabular}

values rounded / * Mean values from [MI] \& [MIC] \& [MC] \& [MDIC] / ** Mean values from [ISCa] \& [ISCb] 
energy balances,

$\mathrm{CO}_{2}$ balances,

recycling rates or

economic efficiency.

On this basis it will be possible to compare the sustainability effects, including effects pertaining to employment, of goods made from primary raw materials and those made from secondary raw materials resulting from separate collection and the reprocessing process.

\section{CONCLUSIONS AND OUTLOOK}

The result of this work shows that there is a great employment potential for the treatment of residual waste. A shift from $100 \%$ waste incineration to improved separate collection allows for a tripling of the number of direct jobs, and thus hundreds of jobs for Austria and tens of thousands of jobs for the EU. Against this background, the EU assumption of creating some 170,000 jobs by 2030 by shifting to a circular economy (EC, 2015) seems very conservative.

This estimate holds good, even as it is one limitation of our work that we had to simplify our models: Especially as to collection modes and the means of transport we had to take simplifying assumptions, which might influence the impact on employment significantly. Here, an adaptation to real-world situations might be useful.

Another limitation is the absence of unified statistical data, as a guideline for standardized residual waste analysis has only been in place since 2017 (BMLFUW, 2017). Finally, we have to take into account as a limitation that an increase in recycling over simpler ways of waste treatment could involve sinking marginal labor intensity in the recycling sector. This diminishes the chance of linearly scaling the model up to a significant rise in recycling rates.

Further room for research would involve a more intense consideration of reuse which can yield a hundredfold employment effect, but also considering bulky waste or different types of collection points for recoverables provide additional starting points. Further research could also extend to energy or $\mathrm{CO}_{2}$ balances.

It will be important to consider indirect and induced interdependencies as researched by WIFO: More sophisticated waste management systems contribute to job creation and economic performance, but they also cause higher (domestic) energy consumption due to the different forms of treatment. In models 3 and 4, however, this can be partly made up for by generating heat and thus substituting fossil energy. Furthermore, models 4 add to the substitution of primary raw materials and thus to a lower (global) energy consumption and $\mathrm{CO}_{2}$ emission.

This results in more sophisticated waste management systems contributing to the EU waste hierarchy in a more satisfactory way (including a substantial contribution to a circular economy with lower demand for primary resources). Additional positive environmental effects pertain to avoiding exhaust air and wastewater emissions from landfilling and incineration (Meyer \& Sommer 2019).

The key to success especially as to implementing an improved collection is education and awareness-raising among the general public (Gelbmann \& Zimek 2018). The aim should be for all actors to cooperate in a systemic way. Thus, a shift in waste management also requires the adaptation of legal regulations, more transparency, product responsibility already at the generation of products stage or mergers in regions for waste disposal. This will pave the way from linear growth to a circular economy.

\section{ACKNOWLEDGEMENTS}

Contents of this article were mainly taken from the master thesis of the co-author Altendorfer. More details and information can be found in the full master's thesis.

\section{REFERENCES}

Altendorfer, M. (2018). Vergleich abfallwirtschaftlicher Systeme für Siedlungsabfälle mit Schwerpunkt Beschäftigungseffekte. Retrieved from http://unipub.uni-graz.at/urn:nbn:at:at-ubg:1-131986

Amt der Kärntner Landesregierung (Hrsg.). (2012). Kärntner Abfallbericht und Abfallwirtschaftskonzept: 3. Fortschreibung 2012. Retrieved August 31, 2017, from https://www.ktn.gv.at/Service/ Publikationen?kid=18

Amt der Niederösterreichischen Landesregierung (Hrsg.). (2011). Niederösterreichische Restmüllanalyse und Detailanalyse der Feinfraktion 2010 - 2011. Retrieved September 3, 2017, from http:// www.noe.gv.at/noe/Abfall/Restmuellanalyse_2010_-_2011.html

BMLFUW. (2015). Die Bestandsaufnahme der Abfallwirtschaft in Österreich: Statusbericht 2015. Vienna: Federal Ministry of Agriculture, Forestry, Environment and Water Management. Retrieved August 16, 2017, from https://www.bmlfuw.gv.at/dam/jcr:dcb379ae9512-4c8f-bfb9-d4b0409fa238/AW_Statusbericht_2015_final.pdf

BMLFUW. (2017). Leitfaden für die Durchführung von Restmüll-Sortieranalysen. Wien: Federal Ministry of Agriculture, Forestry, Environment and Water Management.

BMNT. (2017). Bundes-Abfallwirtschaftsplan 2017. Vienna: Federal Ministry for Sustainability and Tourism. Retrieved February 1, 2018, from https://www.bmnt.gv.at/umwelt/abfall-ressourcen/bundesabfallwirtschaftsplan/BAWP2017-Final.html

Brunner, P., Allesch, A., Getzner, M., Huber-Humer, M., Pomberger, R. [R], Müller, W., ... Kreindl, G., et al. (2015). Benchmarking für die österreichische Abfallwirtschaft. Vienna: Technical University of Vienna, Institute for Water Quality and Resource Management. Retrieved July 20, 2017, from https://www.bmlfuw.gv.at/greentec/ abfall-ressourcen/Benchmarking-Studie.html

Döring, N. \& Bortz, J. (2016). Forschungsmethoden und Evaluation in den Sozial- und Humanwissenschaften. Retrieved from http:// dx.doi.org/10.1007/978-3-642-41089-5

EC European Commission. (2015). Circular Economy - Closing the loop: Clear targets and tools for better waste management. European Commission. Retrieved August 22, 2017, from https:// ec.europa.eu/commission/sites/beta-political/files/circular-economy-factsheet-waste-management_en.pdf

EC European Commission. (2018). A Clean Planet for all - A European strategic long-term vision for a prosperous, modern, competitive and climate neutral economy. European Commission. Retrieved January 6, 2021, from https://eur-lex.europa.eu/legal-content/EN/ TXT/HTML/?uri=CELEX:52018DC0773\&from=DE

EC European Commission. (2019). The European Green Deal. European Commission. Retrieved January 6, 2021, from https://eur-lex. europa.eu/legal-content/EN/TXT/?qid=1588580774040\&uri=CEL EX:52019DC0640

Eurostat. (2018). Municipal waste statistics. Retrieved April 4, 2018, from http://ec.europa.eu/eurostat/statistics-explained/index.php/ Municipal_waste_statistics\#Main_tables

FHAanalytik and TB Hauer. (2010). Restmüllanalysen Tirol 2010. Korneuburg. Retrieved September 3, 2017, from https://www.tirol. gv.at/fileadmin/themen/umwelt/abfallwirtschaft/downloads/ restmuellanalyse_2010.pdf

Flick, U. (2011). Triangulation: Eine Einführung (3rd, updated edition.). 
Frischenschlager, H., Karigl, B., Lampert, C., Pölz, W., Schindler, I., Tesar, M., ... Winter, B. (2010). Klimarelevanz ausgewählter Recycling-Prozesse in Österreich: Endbericht. Vienna: Umweltbundesamt GmbH. Retrieved September 24, 2017, from http://www. umweltbundesamt.at/fileadmin/site/publikationen/REP0303.pdf

Gelbmann, U. \& Zimek, M. (2018). Enticing Consumers to Avoid Waste - Digital and Analogue Ways of Raising Their Awareness. In Pomberger, R., Adam, J., Aldrian, A., Kranzinger, L., Lorber, K., Neuhold, S., ... Weißenbach, T. (Eds.), Recy \& DepoTech 2018: POSTER-Konferenzband zur 14. Recy \& DepoTech-Konferenz (pp. 407-414). Leoben: Montanuniversität.

Gibbs, A., Elliott, T., Ballinger, A., Hogg, D., Gentil, E., Fischer, C., \& Bakas, I. (2014a). Development of a Modelling Tool on Waste Generation and Management. Appendix 9: Employment in Municipal Waste Management Operations. In Development of a Modelling Tool on Waste Generation and Management. European Commission DG. Retrieved September 13, 2017, from http://ec.europa.eu/environment/waste/target_review.htm.

Gibbs, A., Elliott, T., Vergunst, T., Ballinger, A., Hogg, D., Gentil, E., ... Bakas, I. (2014b). Development of a Modelling Tool on Waste Generation and Management. European Commission DG. Retrieved September 13, 2017, from http://ec.europa.eu/environment/waste/target_review.htm.

Hogg, D., Vergunst, T., Elliott, T., Elliott, L., Corbin, M., \& Ballinger, A. (2015). Further development of the European reference model on waste generation and management. Eunomia. Retrieved September 13, 2017, from https://publications.europa.eu/de/publicationdetail/-/publication/d188ce6e-9cac-11e5-b792-01aa75ed71a1/ language-en/format-PDF/source-38735912

Hogg, D., Vergunst, T., Elliott, T., Elliott, L., \& Corbin, M. (2016). Support to the waste targets review. Appendix 1: Analysis for new policy options. In Support to the waste targets review: final report. Eunomia. Retrieved September 13, 2017, from http://ec.europa.eu/ environment/waste/target_review.htm

Hug, T. (2015). Empirisch forschen: die Planung und Umsetzung von Projekten im Studium (2nd, revised. Ed.). Konstanz: UVK. Retrieved from http:// deposit. d -nb.de/cgi-bin/ dokserv?id=4817804\&prov=M\&dok_var=1\&dok_ext=htm
Klampfl-Pernold, H. \& Gelbmann, U. (2006). Quantensprünge in der Abfallwirtschaft: Entwicklung eines innovationsorientierten Phasenmodells der europäischen Abfallwirtschaft. Aachen: Shaker.

Kranzinger, L., Schopf, K., Pomberger, R., \& Punesch, E. (2017). Case study: Is the 'catch-all-plastics bin' useful in unlocking the hidden resource potential in the residual waste collection system? Waste Management and Research, (35(2)), 155-162. Retrieved February 19, 2018, from http://journals.sagepub.com/doi/ abs $/ 10.1177 / 0734242 \times 16682608$

Meyer, I. \& Sommer, M. (2019). Beschäftigungseffekte abfallwirtschaftlicher Modelle der Restmüllbehandlung. Wien: WIFO. Retrieved May 31, 2019, from https://www.wifo.ac.at/publikationen/ publikationssuche?detail-view=yes\&publikation_id $=61774$

Neitsch, M. \& Wagner, M. (2017). RepaNet Markterhebung 2015: Re- Use im Aufwind. Zahlen und Potential von Re-Use-Mengen und Beschäftigung im Re-Use-Sektor in Österreich. RepaNet. Retrieved May 24, 2018, from http://www.repanet.at/re-use-in-oesterreich-im-aufwind/

ÖÖI \& TBH. (2012). Analyse von kommunalem Restabfall sowie von getrennt gesammelten biogenen Abfällen in Vorarlberg 2012. Korneuburg: Umweltverband Vorarlberg.

Stadt Wien. (2016). MA 48 - Abfallwirtschaft, Straßenreinigung und Fuhrpark. Vienna. Retrieved August 16, 2017, from https://www. wien.gv.at/umwelt/ma48/service/publikationen/

Tamma, P. \&Hervey, G. (2018). Hope for circular economy jobs could be a waste. Retrieved May 24, 2018, from https://www.politico.eu/ article/circular-economy-jobs-waste-garbage-trash-recycling/

TB Hauer. (2010). Restmüllanalysen 2010. Retrieved September 3, 2017, from www.bmv.at/uploads/media/Restmuellanalyse_2010.pdf

VOEB. (2017). Mitglieder. Verband Österreichischer Entsorgungsbetriebe. Retrieved December 5, 2017, from http://www.voeb.at/ mitglieder/mitgliederliste/

Weingärtler, M. (2009). Die österreichische Entsorgungswirtschaft: Daten und Fakten. Vienna: Institut für Strategieanalysen. Retrieved August 11, 2017, from http://www.voeb.at/fileadmin/user_ upload/voeeb.at/Dokumente/Branchenstudie/Studie_Entsorgungswirtschaft_Zwischenbericht_01.pdf

\section{APPENDIX}

TABLE A1: Transport: loading weight, transport routes and employment per 100,000 tons per year for the individual transports

\begin{tabular}{|c|c|c|c|c|}
\hline abbreviation & transport route designation & $\begin{array}{l}\text { loading } \\
\text { weight }[\mathrm{t}]\end{array}$ & $\begin{array}{l}\text { transport } \\
\text { route }[\mathrm{km}]\end{array}$ & $\begin{array}{c}\text { employees } \\
\text { per } 100,000 t\end{array}$ \\
\hline WI-G - LF-R & waste incineration plant with grate firing $>>$ residual waste landfill & 20 & 50 & 9.0 \\
\hline WI-G - L-Shr & waste incineration plant with grate firing >> large shredder plant & 25 & 100 & 12.0 \\
\hline WI-F - LF-R & waste incineration plant with fluidised bed combustion $\gg>$ residual waste landfill & 20 & 50 & 9.0 \\
\hline MBT - LF-M & MBT plant $\gg>$ mass waste landfill & 20 & 0 & 0.0 \\
\hline MBT - WI-F & MBT plant >> waste incineration plant with fluidised bed combustion & 11 & 100 & 27.3 \\
\hline MBT - SFP-P & MBT plant $>>$ substitute fuel production plant & 11 & 50 & 16.4 \\
\hline MBT - Cem & MBT plant $>>$ waste co-incineration plant with rotary kiln in the cement plant & 11 & 150 & 32.8 \\
\hline MBT - L-Shr & MBT plant $>>$ large shredder plant & 25 & 100 & 12.0 \\
\hline SFP-P - Cem & substitute fuel production plant $>>$ waste co-incineration plant with rotary kiln in the cement plant & 11 & 150 & 32.8 \\
\hline L-Shr - P-Shr & large shredder plant >> post shredder plant & 25 & 0 & 0.0 \\
\hline L-Shr - Met-Ind & large shredder plant $>>$ metal industry & 25 & 200 & 19.2 \\
\hline Po-Sh - Met-Ind & post shredder plant >> metal industry & 25 & 200 & 19.2 \\
\hline LWP-S - MBT & lightweight packaging sorting plant $>>$ MBT plant & 20 & 100 & 15.0 \\
\hline LWP-S - SFP-P & lightweight packaging sorting plant $>>$ substitute fuel production plant & 11 & 50 & 16.4 \\
\hline LWP-S - Pla-R & lightweight packaging sorting plant $>>$ plastic recycling plant & 11 & 200 & 43.7 \\
\hline Pla-R - WI-F & plastic recycling plant $>>$ waste incineration plant with fluidised bed combustion & 11 & 150 & 32.8 \\
\hline Comp - MBT & composting plant $>>$ MBT plant & 20 & 50 & 9.0 \\
\hline Pap-S - Pap-M & wastepaper sorting plant $\gg>$ paper mill & 20 & 50 & 9.0 \\
\hline Pap-S - MBT & wastepaper sorting plant $>>$ MBT plant & 20 & 150 & 18.0 \\
\hline $\mathrm{Gl}-\mathrm{T}-\mathrm{Gl}-\mathrm{S}$ & waste glass transfer station $>>$ waste glass sorting plant & 25 & 200 & 19.2 \\
\hline GI-S - MBT & waste glass sorting plant >> MBT plant & 20 & 150 & 18.0 \\
\hline Met-T - L-Shr & scrap metal transfer station >> large shredder plant & 25 & 200 & 19.2 \\
\hline
\end{tabular}

